\title{
REVIEW ARTICLE OPEN \\ A systematic review of psychological, physical health factors, and quality of life in adult asthma
}

\author{
Sabina Stanescu $\mathbb{D}^{1 *}$, Sarah E. Kirby ${ }^{1,2}$, Mike Thomas $\mathbb{D}^{2,3}$, Lucy Yardley ${ }^{1}$ and Ben Ainsworth ${ }^{4}$
}

\begin{abstract}
Asthma is a common non-communicable disease, often characterized by activity limitation, negative effects on social life and relationships, problems with finding and keeping employment, and poor quality of life. The objective of the present study was to conduct a systematic review of the literature investigating the potential factors impacting quality of life (QoL) in asthma. Electronic searches were carried out on: MEDLINE, EMBASE, PsycINFO, the Cochrane Library, and Web of Science (initial search April 2017 and updated in January 2019). All primary research studies including asthma, psychological or physical health factors, and quality of life were included. Narrative synthesis was used to develop themes among findings in included studies in an attempt to identify variables impacting QoL in asthma. The search retrieved 43 eligible studies that were grouped in three themes: psychological factors (including anxiety and depression, other mental health conditions, illness representations, and emotion regulation), physical health factors (including BMI and chronic physical conditions), and multifactorial aspects, including the interplay of health and psychological factors and asthma. These were found to have a substantial impact on QoL in asthma, both directly and indirectly, by affecting self-management, activity levels and other outcomes. Findings suggest a complex and negative effect of health and psychological factors on QoL in asthma. The experience of living with asthma is multifaceted, and future research and intervention development studies should take this into account, as well as the variety of variables interacting and affecting the person.
\end{abstract}

npj Primary Care Respiratory Medicine (2019)29:37

; https://doi.org/10.1038/s41533-019-0149-3

\section{INTRODUCTION}

Over 235 million people worldwide are living with asthma, which is one of the leading non-communicable diseases worldwide. ${ }^{1,2}$ Symptoms, exacerbations, and triggers in asthma are associated with lower quality of life (QoL), tiredness, activity limitation, negative effects on social life and relationships, problems with finding and keeping employment, and reduced productivity. ${ }^{3-7}$ People with asthma are up to six times more likely than the general population to have anxiety or depression, ${ }^{8}$ and $16 \%$ of people with asthma in the UK have panic disorder, ${ }^{9}$ compared to $1 \%$ in the general population. ${ }^{10}$ People with brittle asthma (difficult-to-control asthma with severe, recurrent attacks) demonstrate even greater comorbidity and maladaptive coping styles. ${ }^{11}$ Psychological dysfunction is often unrecognized in primary care, despite being significantly associated with poor asthma outcomes, including asthma control and QoL. ${ }^{8,12,13}$ Indeed, the European Asthma Research and Innovation Partnership has identified understanding the role of psychological factors as an unmet need in improving asthma outcomes. ${ }^{14,15}$ They propose that anxiety and depression are present at all three stages of the experience of asthma: onset, progression, and exacerbation. ${ }^{14}$

A recent meta-analysis found that asthma diagnoses significantly increased the risk of psychological and health conditions (such as cardiovascular/cerebrovascular diseases, obesity, hypertension, diabetes, psychiatric and neurological comorbidities, gut and urinary conditions, cancer, and respiratory problems other than asthma). ${ }^{16}$ In addition, studies have pointed towards an impact on QoL in people with asthma of additional health and psychological factors, such as comorbid anxiety or depression, higher body mass index(BMI), professional status, and feelings of lack of control over health (for example, refs ${ }^{17,18}$ ). Such evidence reinforces the argument that the needs of people with asthma should be approached in conjunction with these additional factors, rather than using a single-illness approach, aiming to reduce the adversity of people's experience. However, the extent to which psychological and physical health factors interact and impact asthma outcomes is yet to be systematically explored. This systematic review aims to provide a narrative synthesis of the literature exploring psychological and physical health factors that influence QoL in adults with asthma.

\section{RESULTS}

Study characteristics

The search and screening process identified 43 eligible papers, published between 2003 and 2019 (see Fig. 1 for PRISMA flowchart ${ }^{19}$ ). The characteristics of each study are summarized below in Table 1. Twelve studies were conducted in Europe, ${ }^{20-31}$ 17 in North America, ${ }^{12,32-47} 7$ in Australia, ${ }^{17,48-53} 4$ in Asia, ${ }^{54-57}$ and 3 in Africa. ${ }^{58-60}$ All papers employed a quantitative approach comprising 2 longitudinal studies ${ }^{31,44}$ and 41 cross-sectional studies. Only 4 studies included a control group. . $^{21,28,29,31}$ Overall, the majority of papers had a large sample size (ranging between 40 and 39,321 participants; 30 papers included a sample size of $>100$ ). The majority of studies recruited from primary care or the general population, using self-report to confirm a diagnosis of asthma. Only a few studies recruited from secondary and tertiary asthma clinics. ${ }^{12,27,36,41,44,48,60}$ There was a high occurrence $(n=14)$ of exclusion criteria relating to specific demographic or asthma characteristics, as well as mental health conditions and comorbidities, which restricted the study sample without a reason being given. Most studies used self-report

\footnotetext{
${ }^{1}$ Academic Unit of Psychology, University of Southampton, Southampton, UK. ${ }^{2}$ NIHR Southampton Respiratory Biomedical Research Unit, University of Southampton, Southampton, UK. ${ }^{3}$ Primary Care and Population Sciences, University of Southampton, Southampton, UK. ${ }^{4}$ Department of Psychology, University of Bath, Bath, UK. *email: s.stanescu@soton.ac.uk
} 


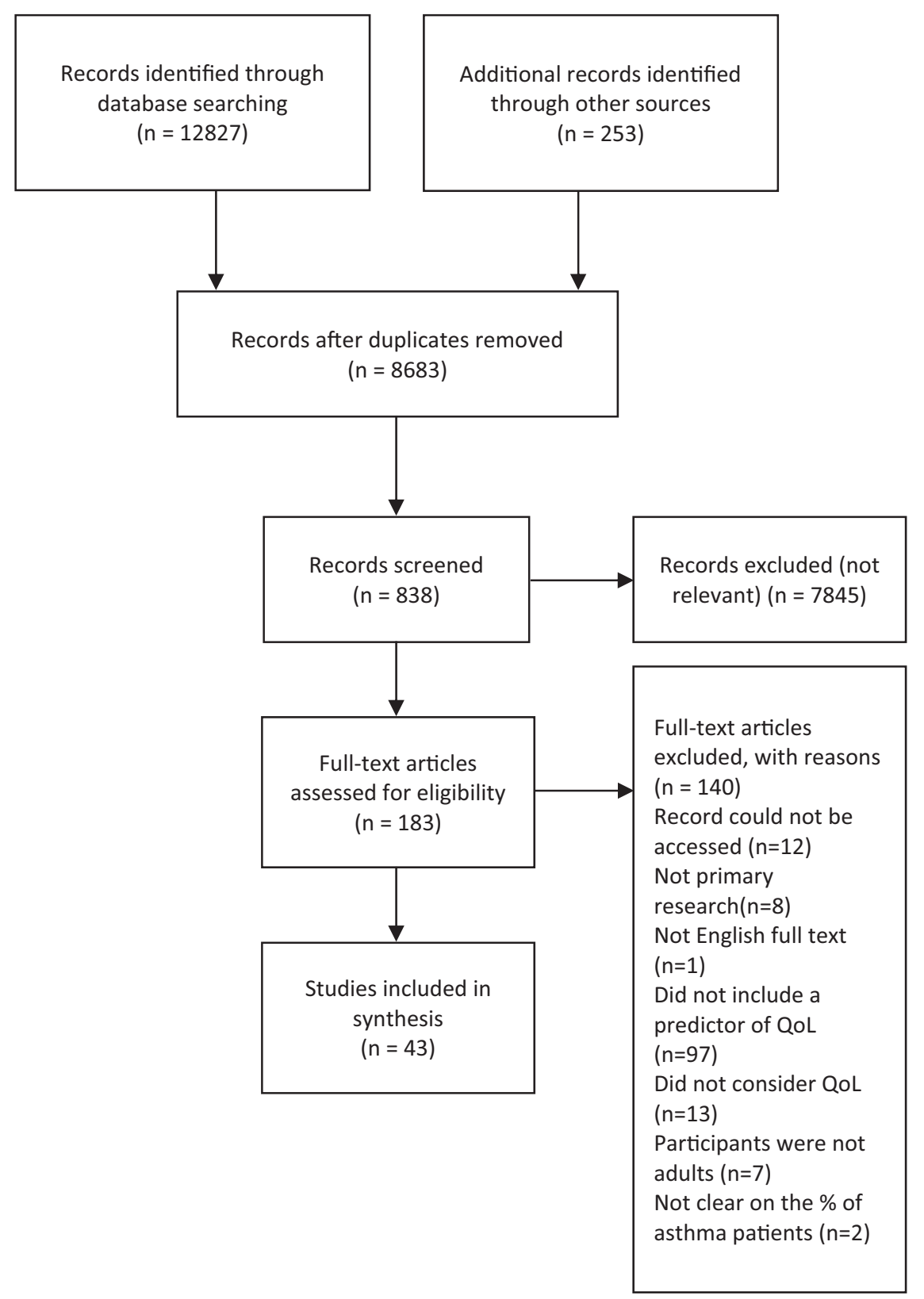

Fig. 1 PRISMA statement of included and excluded papers

measures, ${ }^{17,20-30,32-37,39,41-46,48,49,51-60}$ with a small proportion using psychiatric interviews to screen for mental health conditions. ${ }^{12,31,38,40,50}$ The majority of studies used asthma-specific QoL measures $(n=29), 12,21,23,25,27,28,30,32-37,39-42,44,48-51,54-56,58-61$ 17 included an health-related QoL measure $(n=18),{ }^{17,20,22-25,28,30,31,34-36,38,43,50-52,55}$ and 4 used general measures of QoL $(n=7) ; 26,35,45-47,57,6211$ papers used $>1$ measure of QoL. $23,25,28,30,34-37,50,51,55$ The average age across included studies was 42.1 years (and $61.57 \%$ were female). Papers report prevalence rates of between $16.8 \%$ and $48.9 \%$ for depression and between $13.3 \%$ and $44.4 \%$ for anxiety, ${ }^{20,27,33,38,50,56,58,60}$ with an average of $28.31 \%$ for a diagnosis of anxiety or depression. Across several studies, the prevalence of other mental health conditions was $28.31 \%$ on average (ranging between $28 \%$ and $80 \%$ ). ${ }^{12,37,38,40,42}$ Between $72 \%$ and $86.9 \%$ of people with asthma had at least one additional physical condition and between $21 \%$ and $26.3 \%$ had $\geq 2 i^{25,34,56} 26.36 \%$ had, on average, at least one other physical health condition. On average, people with asthma were significantly more likely to have a BMI of $>30$ (and between $61 \%$ and $75.1 \%$ had a $\mathrm{BMI}>25)^{26,45,59}$ The quality assessment identified that most studies were of a reasonable quality; however, it should be noted that some measures used could be considered inappropriate for the research aim or the population under investigation. Examples include measuring general QoL with an asthma-specific measure or administering a geriatric depression questionnaire to a young adult population.

Narrative synthesis

Narrative synthesis generated three overarching themes: psychological factors, health factors, and multifactorial aspects (see Table 2 for themes and subtheme descriptions). Overall, patients with asthma demonstrated impaired QoL, which was further decreased by psychological factors (e.g. anxiety, depression, emotion regulation, illness perceptions), health risk factors (such as an increased $\mathrm{BMI}$ ), and the presence of a co-existing mental health or 


\begin{tabular}{|c|c|c|c|c|c|}
\hline $\begin{array}{l}\text { Adams } \\
\text { et al. }{ }^{71}\end{array}$ & $\begin{array}{l}7619 \text { people from } \\
\text { the general } \\
\text { population ( } 834 \text { with } \\
\text { asthma) }\end{array}$ & $\begin{array}{l}\text { Cross-sectional, population } \\
\text { household interview }\end{array}$ & $\begin{array}{l}\text { Kessler Psychological Distress Scale } \\
\text { (K10), for a global measure of } \\
\text { psychological distress, containing } \\
\text { measures of depressive and anxiety } \\
\text { symptoms experienced over } 4 \text { weeks } \\
\text { +self-report of diagnosed psychiatric } \\
\text { conditions }\end{array}$ & SF-12 & $\begin{array}{l}\text { Psychological distress was more common in people } \\
\text { with asthma (17.9\% v } 12.2 \%, p<0.01) \text {; mental health } \\
\text { conditions were more common }(16.2 \% \text { vs } 12.2 \%, p< \\
0.01) \\
\text { People with asthma and psychological distress had } \\
\text { significantly lower QoL than those with either asthma } \\
\text { or psychological distress alone (the physical } \\
\text { component summary of the SF-12). Among those with } \\
\text { psychological distress, the mental component } \\
\text { summary did not differ between people with or } \\
\text { without asthma }\end{array}$ \\
\hline $\begin{array}{l}\text { Adams } \\
\text { et al. } .^{11}\end{array}$ & $\begin{array}{l}293 \text { adults with } \\
\text { asthma, at baseline } \\
\text { and } 232 \text { at } \\
12 \text { months }\end{array}$ & $\begin{array}{l}\text { Longitudinal study (measures } \\
\text { at baseline and 12-month } \\
\text { follow-up), patients recruited } \\
\text { from outpatient clinics, } \\
\text { emergency departments and } \\
\text { inpatients at } 2 \text { hospitals }\end{array}$ & $\begin{array}{l}\text { Coping scales to measure active, } \\
\text { avoidance, and denial coping, as well } \\
\text { as other measures such as-self- } \\
\text { efficacy in asthma, perceived } \\
\text { emotional and social support, } \\
\text { satisfaction with illness scale }\end{array}$ & $\begin{array}{l}\text { SF-36 and the Modified } \\
\text { Marks AQLQ }\end{array}$ & $\begin{array}{l}\text { Avoidance coping and clinical asthma status were } \\
\text { significant predictors of the Marks AQLQ and the } \\
\text { physical and mental components of the SF-36 in a } \\
\text { regression model. Less avoidance was associated in an } \\
\text { increase greater than one standard deviation for all } \\
\text { scales. Similar trends were observed for active coping } \\
\text { and self-efficacy but not denial. Active coping was a } \\
\text { significant predictor of the physical component ( } r^{2}= \\
\text { o.69) and satisfaction with illiness was a significant } \\
\text { predictor of the mental component }\left(r^{2}=0.54\right)\end{array}$ \\
\hline $\begin{array}{l}\text { Adeyeye } \\
\text { et al. }{ }^{.6}\end{array}$ & $\begin{array}{l}201 \text { adult } \\
\text { participants with } \\
\text { moderate and } \\
\text { severe asthma }\end{array}$ & $\begin{array}{l}\text { Cross-sectional, recruited from } \\
\text { an asthma outpatient clinic }\end{array}$ & $\begin{array}{l}\text { The Mini International } \\
\text { Neuropsychiatric Interview (M.I.I.I) to } \\
\text { assess the presence of anxiety and/or } \\
\text { depression }\end{array}$ & Mini-AQLQ & $\begin{array}{l}\text { Presence of anxiety/depression was a significant } \\
\text { independent predictor of the mini-AQLQ score and of } \\
\text { the emotional domain }(p<0.001)\end{array}$ \\
\hline Afari et al. ${ }^{38}$ & $\begin{array}{l}50 \text { adult participants } \\
\text { with } \\
\text { confirmed asthma }\end{array}$ & $\begin{array}{l}\text { Cross-sectional, recruited from } \\
\text { an asthma clinic }\end{array}$ & $\begin{array}{l}\text { Diagnostic Interview Schedule for } \\
\text { DSM-III-R }\end{array}$ & SF-36 & $\begin{array}{l}\text { Asthma patients with a lifetime diagnosis of } \\
\text { depression reported worse physical functioning, } \\
\text { mental health functioning, and health perceptions (Fs } \\
\text { ranged between } 2.60 \text { and } 4.18, p s<0.05 \text {. Scores for } \\
\text { anxiety followed similar trends but were non- } \\
\text { significant }\end{array}$ \\
\hline $\begin{array}{l}\text { Bohmer } \\
\text { et al. }\end{array}$ & $\begin{array}{l}196 \text { participants with } \\
\text { a main diagnosis } \\
\text { of asthma }\end{array}$ & $\begin{array}{l}\text { Cross-sectional, recruited for a } \\
\text { different study from primary } \\
\text { and specialist practices }\end{array}$ & HADS & SF-12 & $\begin{array}{l}\text { Scores for both anxiety and depression were } \\
\text { significantly associated with worse Qol on the } \\
\text { physical and mental dimensions. Increasing age, } \\
\text { female gender, higher number of medications, and } \\
\text { symptoms of depression explained } 48 \% \text { of the } \\
\text { variance in the physical component. Living alone and } \\
\text { reporting symptoms of anxiety explained } 33 \% \text { of the } \\
\text { variance in the mental component }\end{array}$ \\
\hline Choi et al. ${ }^{56}$ & $\begin{array}{l}202 \text { patients: } 127 \\
\text { non-elderly }(20-64 \\
\text { years) and } 75 \text { elderly } \\
\text { (>65 years) patients } \\
\text { with asthma }\end{array}$ & $\begin{array}{l}\text { Cross-sectional, recruited from } \\
\text { five allergy and asthma clinics }\end{array}$ & Korean version of the PHQ-9 & Asthma-Specific QOL (AQOL) & $\begin{array}{l}\text { AQOL scores were significantly lower for people with } \\
\text { depression and asthma }(72.4 \text { vs } 98.6, p<0.011) \text {; this was } \\
\text { true for both groups (elderly and non-elderly) } \\
\text { Within the elderly group, a higher BMI was } \\
\text { significantly associated with depression. } \\
\text { Comorbidities (yes/no) were not more or less } \\
\text { prevalent in people with or without depression }\end{array}$ \\
\hline $\begin{array}{l}\text { Coban and } \\
\text { Aydemir }\end{array}$ & $\begin{array}{l}174 \text { adults } \\
\text { with asthma }\end{array}$ & $\begin{array}{l}\text { Cross-sectional, consecutive } \\
\text { patients recruited from } \\
\text { secondary care }\end{array}$ & HADs and allergic status & AQLQ & $\begin{array}{l}\text { There was no difference between people who had } \\
\text { atopic and non-atopic asthma in terms of anxiety, } \\
\text { depression, or QoL. } \\
\text { Participants with a higher general anxiety and } \\
\text { depression score had lower QoL }(3.62 \text { vs } 4.68, p<0.01 \\
\text { for anxiety and } 3.81 \text { vs } 4.80, p<0.01 \text { for depression). } \\
\text { Average scores for people with asthma and anxiety } \\
\text { and/or depression were worse than one standard } \\
\text { deviation when compared with people with asthma } \\
\text { but without anxiety/depression }\end{array}$ \\
\hline
\end{tabular}


Table 1 continued

\begin{tabular}{|c|c|c|c|c|c|}
\hline Study & Sample & Study design and recruitment & Predictor & QoL measurement & Findings-summary \\
\hline $\begin{array}{l}\text { Deshmukh } \\
\text { et al. }{ }^{61}\end{array}$ & $\begin{array}{l}110 \text { adult patients } \\
\text { with asthma }\end{array}$ & $\begin{array}{l}\text { Cross-sectional, recruited } \\
\text { patients who visited an } \\
\text { emergency department in the } \\
\text { past } 18 \text { months }\end{array}$ & HADs & AQLQ & $\begin{array}{l}\text { Anxiety }\left(R^{2}=0.128\right) \text { was a significant predictor of } \\
\text { AQLQ. Having anxiety was correlated with having } \\
\text { depression }(F=27.17, p<0.001) \text {. People with anxiety } \\
\text { and depression had significantly lower QoL scores } \\
(F=11.54 \text { for anxiety and } F=26.3 \text { for depression } p< \\
0.001) \text {. Overall, symptoms of anxiety and depression } \\
\text { accounted for } 28.3 \% \text {; anxiety was significantly } \\
\text { correlated with emotional functioning and response } \\
\text { to environmental stimuli (subscales of the AQLQ) } \\
\text { when controlling for depression }\end{array}$ \\
\hline Ekici et al. ${ }^{28}$ & $\begin{array}{l}116 \text { adult asthma } \\
\text { patients and } 116 \\
\text { matched healthy } \\
\text { controls }\end{array}$ & $\begin{array}{l}\text { Cross-sectional, recruited from } \\
\text { a respiratory disease clinic } \\
\text { (matched controls recruited } \\
\text { from the community of visitors } \\
\text { to the same hospital) }\end{array}$ & $\begin{array}{l}\text { Negative mood was evaluated with a } \\
\text { questionnaire including six mood } \\
\text { subscales in } 3 \text { categories- } \\
\text { nervous-anxious, hostile-angry, and } \\
\text { fearful-panicky }\end{array}$ & SF-36 and AQLQ & $\begin{array}{l}\text { Negative mood scores were not different between } \\
\text { people with or without asthma } \\
\text { Both components of the SF- } 36 \text { (mental and physical) } \\
\text { were worse in people with asthma. They were } \\
\text { associated with negative mood scores ( } \beta=-0.37 \text { and } \\
\beta=-0.28, p s<0.01 \text {, respectively) } \\
\text { Negative mood accounted for } 67 \% \text { of the variance in } \\
\text { AQLQ (the impact of negative mood on symptoms } \\
\text { and activity domains of the AQLQ was significant but } \\
\text { not the emotional and environmental domains) }\end{array}$ \\
\hline $\begin{array}{l}\text { Erickson } \\
\text { et al. }^{34}\end{array}$ & $\begin{array}{l}603 \text { adults } \\
\text { with asthma }\end{array}$ & $\begin{array}{l}\text { Cross-sectional, recruited } \\
\text { patients who were enrolled in a } \\
\text { managed care organization }\end{array}$ & $\begin{array}{l}\text { Number of comorbidities and health } \\
\text { belief questionnaires (based on the } \\
\text { Health Belief Model) }\end{array}$ & AQLQ and SF-36 & $\begin{array}{l}\text { Number of comorbidities was significantly associated } \\
\text { with decreased QoL on all } 10 \text { components and the } \\
\text { overall score ( } \beta \text { ranging from }-0.062 \text { to }-0.360 \text {, } \\
\text { significant for summary AQLQ, activity limitation, } \\
\text { symptoms and exposure to environmental stimuli, } \\
\text { and all components of the SF- } 36 \text {, including composite } \\
\text { mental and physical summaries) } \\
\text { illness perceptions (symptom-derived severity and } \\
\text { perceived severity) were both significant predictors of } \\
\text { the physical component of the SF- } 36 \text { and of all } \\
\text { subscales of the AQLQ ( } \beta \text { values ranged from }-0.155 \\
\text { to }-0.237 \text { ) }\end{array}$ \\
\hline $\begin{array}{l}\text { Favreau } \\
\text { et al. }{ }^{44}\end{array}$ & $\begin{array}{l}643 \text { adults } \\
\text { with asthma }\end{array}$ & $\begin{array}{l}\text { Longitudinal, } 4.3 \text { year follow- } \\
\text { up, recruited from tertiary care }\end{array}$ & $\begin{array}{l}\text { Primary care evaluation of mental } \\
\text { disorders interview (to assess panic } \\
\text { disorder), anxiety sensitivity index (to } \\
\text { assess panic-anxiety) }\end{array}$ & AQLQ & $\begin{array}{l}\text { Having a diagnosis of PD did not significantly predict } \\
\text { total AQLQ scores. Higher anxiety sensitivity at } \\
\text { baseline predicted worse symptoms }(\beta=-0.013, p< \\
0.01) \text { and emotional distress }(\beta=-0.014, p<0.01) \text { but } \\
\text { not overall AQLQ. This stayed true when controlling } \\
\text { for covariates (age, gender, years of education, } \\
\text { smoking, major depression, medication use, and } \\
\text { baseline scores) }\end{array}$ \\
\hline Faye et al. ${ }^{57}$ & $\begin{array}{l}60 \text { adults } \\
\text { with asthma }\end{array}$ & $\begin{array}{l}\text { Cross-sectional, consecutive } \\
\text { patients recruited from an } \\
\text { outpatient tertiary care } \\
\text { respiratory hospital }\end{array}$ & $\begin{array}{l}\text { DSM-IV-TR criteria for Panic and } \\
\text { Agoraphobia (including the Panic } \\
\text { and Agoraphobia scale to assess the } \\
\text { severity of panic disorder), number } \\
\text { of comorbidities }\end{array}$ & $\begin{array}{l}\text { WHO QOL BREF scale and the } \\
\text { WHO disability schedule II }\end{array}$ & $\begin{array}{l}83.3 \% \text { of people with } \geq 4 \text { panic symptoms (not } \\
\text { qualifying for panic attack diagnosis) reported } \\
\text { 'sensations of shortness of breath', 'fear of choking' } \\
\text { and 'fear of dying' } \\
\text { QoL scores were significantly lower on the physical } \\
\text { ( } 44.3 \text { vs } 49.3 \text { ) and environmental ( } 43.5 \text { vs } 47.6) \\
\text { domains for participants with panic disorder } \\
\text { compared to those without panic disorder. All } \\
\text { participants with PD had poor QoL (significantly lower } \\
\text { when compared to those without) }\end{array}$ \\
\hline $\begin{array}{l}\text { Goldney } \\
\text { et al. }\end{array}$ & $\begin{array}{l}3010 \text { interviews } \\
\text { conducted ( } 299 \text { with } \\
\text { adults with asthma) }\end{array}$ & $\begin{array}{l}\text { Cross-sectional, population } \\
\text { interview (random sample) }\end{array}$ & $\begin{array}{l}\text { Dyspnoea dimension of the AQLQ to } \\
\text { determine dyspnoea; PRIME-MD } \\
\text { (psychiatric interview tool) to } \\
\text { determine depression }\end{array}$ & AQLQ and SF-36 & $\begin{array}{l}\text { Increases in major depression were associated with } \\
\text { dyspnoea ( } 44.2 \% \text { with depression and dyspnoea, } \\
\text { compared with } 17.9 \% \text { with depression and no } \\
\text { dyspnoea, } p<0.01 \text { ) } \\
\text { This group of people showed significantly lower } \\
\text { scores on all domains of the SF- } 36 \text { (suggesting that } \\
\text { depression could be a mediating factor) }\end{array}$ \\
\hline $\begin{array}{l}\text { Gonzalez- } \\
\text { Barcala } \\
\text { et al. }^{26}\end{array}$ & $\begin{array}{l}2125 \text { adult } \\
\text { participants } \\
\text { with asthma }\end{array}$ & $\begin{array}{l}\text { Multi-stage cross-sectional, } \\
\text { recruited from primary care } \\
\text { clinics }\end{array}$ & $\begin{array}{l}\text { BMI, incidence of stressful events, } \\
\text { presence of allergy sensitization }\end{array}$ & EQ-5D & $\begin{array}{l}32 \% \text { of people with asthma reported 'serious } \\
\text { problems' on the anxiety/depression scale of the EQ- } \\
5 \mathrm{D} \text {. Stressful events of giving little importance to } \\
\text { adherence to treatment were significant predictors of } \\
\text { EQ-5D. Having a BMI of }<25 \text { was significantly } \\
\text { associated with better mobility }(\mathrm{OR}=2.14) \text {, less } \\
\text { activity limitation }(\mathrm{OR}=1.43) \text {, and less pain (OR }= \\
1.75)\end{array}$ \\
\hline $\begin{array}{l}\text { Hommel } \\
\text { et al. }^{32}\end{array}$ & $\begin{array}{l}64 \text { adolescents and } \\
\text { young adults with } \\
\text { asthma (aged } \\
18-25 \text { years) }\end{array}$ & $\begin{array}{l}\text { Cross-sectional, recruited from } \\
\text { the community }\end{array}$ & $\begin{array}{l}\text { IDD (to assess depression), the Beck } \\
\text { Anxiety Inventory, and subjective } \\
\text { illness severity }\end{array}$ & LVAQ & $\begin{array}{l}\text { LVAQ was significantly correlated with subjective } \\
\text { severity }(r=0.48, p<0.01) \text {. The combined influence of } \\
\text { anxiety and depression accounted for } 14 \% \text { of the } \\
\text { variance in QoL; depression contributed significantly } \\
\text { to variance in QoL }(t=2.65 ; p<0.05) \text { before anxiety } \\
\text { was introduced in the model; anxiety demonstrated a } \\
\text { significant main effect on asthma-specific QoL ( } t= \\
2.58 ; p<0.05)\end{array}$ \\
\hline $\begin{array}{l}\text { Hullmann } \\
\text { et al. }{ }^{43}\end{array}$ & $\begin{array}{l}74 \text { adult participants } \\
\text { with asthma (and } 74 \\
\text { with allergies) }\end{array}$ & $\begin{array}{l}\text { Cross-sectional, recruited from } \\
\text { a university }\end{array}$ & $\begin{array}{l}\text { Mishel Uncertainty in Illness Scale-to } \\
\text { assess } 4 \text { components of illness } \\
\text { uncertainty (ambiguity, uncertainty, } \\
\text { lack of information, and } \\
\text { unpredictability); Illness Intrusiveness } \\
\text { Scale-to assess the illness-induced } \\
\text { interference with various life activities }\end{array}$ & SF-36 & $\begin{array}{l}\text { The overall model (including illness uncertainty and } \\
\text { illness intrusiveness, gender, and asthma severity) } \\
\text { accounted for } 59.3 \% \text { of the variance in SF- } 36 \text { scores for } \\
\text { the physical component and } 19.6 \% \text { for the mental } \\
\text { component. Illness intrusiveness and illness } \\
\text { uncertainty were significant independent predictors } \\
\text { of the physical component but not of the mental } \\
\text { component }\end{array}$ \\
\hline $\begin{array}{l}\text { Kolawole } \\
\text { et al. }\end{array}$ & $\begin{array}{l}81 \text { adult patients } \\
\text { with asthma }\end{array}$ & $\begin{array}{l}\text { Cross-sectional, consecutive } \\
\text { patients recruited from an } \\
\text { asthma clinic }\end{array}$ & HADs & Mini-AQLQ & $\begin{array}{l}\text { Presence of anxiety symptoms }\left(\chi^{2}=7.9, p<0.05\right) \text { and } \\
\text { depressive }\left(\chi^{2}=6.45, p<0.05\right) \text { symptoms (according } \\
\text { to HADs) was significantly associated with } \\
\text { decreased QoL. }\end{array}$ \\
\hline $\begin{array}{l}\text { Krauskopf } \\
\text { et al. }{ }^{33}\end{array}$ & $\begin{array}{l}317 \text { participants with } \\
\text { asthma aged over } 60\end{array}$ & $\begin{array}{l}\text { Cross-sectional, recruited from } \\
\text { outpatient health clinics } \\
\text { (secondary care) }\end{array}$ & $\begin{array}{l}\text { PHQ-9 (to assess symptoms of } \\
\text { depression) }\end{array}$ & Mini-AQLQ & $\begin{array}{l}\text { Patients with depression showed poorer quality of life } \\
\text { than those without (mean score difference in AQLQ = } \\
-1.4, p<0.001) \text {. }\end{array}$ \\
\hline
\end{tabular}




\begin{tabular}{|c|c|c|c|c|c|}
\hline Study & Sample & Study design and recruitment & Predictor & QoL measurement & Findings_-summary \\
\hline $\begin{array}{l}\text { Kullowatz } \\
\text { et al. }{ }^{30}\end{array}$ & $\begin{array}{l}88 \text { adult patients } \\
\text { with asthma }\end{array}$ & $\begin{array}{l}\text { Cross-sectional, recruited from } \\
\text { a larger study conducted at a } \\
\text { pulmonary clinic }\end{array}$ & HADs & $\begin{array}{l}\text { Living with asthma } \\
\text { questionnaire (LVAQ) } \\
\text { and SF-12 }\end{array}$ & $\begin{array}{l}\text { After controlling for demographics and symptom } \\
\text { severity, anxiety accounted for considerable variance } \\
\text { in SF-12 mental wellbeing and LAQ psychological } \\
\text { wellbeing (explaining } 22 \% \text { and } 9 \% \text { of the variance, } \\
\text { respectively). Including depression accounted for } \\
\text { additional variance an additional } 8 \% \text { and } 2 \% \text {, } \\
\text { respectively } \\
\text { For physical wellbeing, depression was significantly } \\
\text { associated, explaining } 6 \% \text { of the variance, but not } \\
\text { anxiety } \\
\text { Significant associations were found between anxiety } \\
\text { and depression and the functional subscale of the } \\
\text { LAQ (explaining } 4 \% \text { and } 3 \% \text { of the variance, } \\
\text { respectively) }\end{array}$ \\
\hline $\begin{array}{l}\text { Lavoie } \\
\text { et al. }{ }^{12}\end{array}$ & $\begin{array}{l}406 \text { adult patients } \\
\text { with asthma }\end{array}$ & $\begin{array}{l}\text { Cross-sectional, consecutive } \\
\text { patients recruited from an } \\
\text { asthma clinic }\end{array}$ & $\begin{array}{l}\text { Structured Psychiatric interview-the } \\
\text { Primary Care Evaluation of Mental } \\
\text { Disorders to detect the most common } \\
\text { psychiatric disorders, according to } \\
\text { DSM-IV }\end{array}$ & AQLQ & $\begin{array}{l}\text { Despite no differences in pulmonary functions, people } \\
\text { with psychiatric disorders reported significantly lower } \\
\text { AQLQ on all individual scores and total score (mean } \\
\text { score } 5.3 \text { vs } 4.6, p<0.01 \text { ) }\end{array}$ \\
\hline $\begin{array}{l}\text { Lavoie } \\
\text { et al. }{ }^{40}\end{array}$ & $\begin{array}{l}504 \text { adult patients } \\
\text { with asthma }\end{array}$ & $\begin{array}{l}\text { Cross-sectional, consecutive } \\
\text { patients with asthma recruited } \\
\text { in primary care }\end{array}$ & $\begin{array}{l}\text { Primary Care Evaluation of Mental } \\
\text { Disorders-PRIME-MD }\end{array}$ & AQLQ & $\begin{array}{l}\text { Independent effects of depression on AQLQ }(F=38.5, \\
p<0.01 \text {, and anxiety on AQL }(F=18.06, p<0.01 \\
\text { total score) but no significant interaction effect (the } \\
\text { multiple regression model containing severity, sex, } \\
\text { age, depression, and anxiety and the interaction } \\
\text { accounted for } 22 \% \text { in the interaction). There was a } \\
\text { significant independent effect of depression } \\
\text { (explaining } 3 \% \text { of the variance in AQLQ) and anxiety } \\
\text { (explaining } 1 \% \text { of the variance). They were significant } \\
\text { predictors on every subscale, explaining between } 1 \% \\
\text { and } 3 \% \text { of the variance in AQLQ subscales }\end{array}$ \\
\hline $\begin{array}{l}\text { Lavoie } \\
\text { et al. } .^{42}\end{array}$ & $\begin{array}{l}557 \text { adults } \\
\text { with asthma }\end{array}$ & $\begin{array}{l}\text { Cross-sectional, patients } \\
\text { recruited from a larger study } \\
\text { conducted in tertiary care. }\end{array}$ & $\begin{array}{l}\text { Psychiatric Interview to assess mental } \\
\text { disorders, Asthma Self-Efficacy Scale }\end{array}$ & AQLQ & $\begin{array}{l}\text { ASES scores were significantly correlated with AQLQ, } \\
\text { suggesting that being confident in one's ability to } \\
\text { control asthma symptoms is associated with better } \\
\text { quality of life }(r=0.62, p<0.01) \text {. Lower ASES scores } \\
\text { were also significantly correlated with a higher BMI } \\
\text { and having a comorbid mood or anxiety disorder }\end{array}$ \\
\hline $\begin{array}{l}\text { Lomper } \\
\text { et al. }\end{array}$ & $\begin{array}{l}96 \text { adult patients ( } 33 \\
\text { with controlled } \\
\text { asthma, } 63 \text { with } \\
\text { uncontrolled } \\
\text { asthma) }\end{array}$ & $\begin{array}{l}\text { Cross-sectional, recruited from } \\
\text { an outpatient allergy clinic }\end{array}$ & $\begin{array}{l}\text { HADs (measured both anxiety and } \\
\text { depression but only performed an } \\
\text { analysis of correlations between } \\
\text { depression and QoL }\end{array}$ & SF-36 & $\begin{array}{l}\text { There was a significant difference in the mental } \\
\text { component between people with or without } \\
\text { depression }(51.4 \text { vs } 71.8, p<0.05) \text { in the group of } \\
\text { people with controlled asthma. There was no } \\
\text { significant difference between people with or without } \\
\text { anxiety } \\
\text { In the uncontrolled asthma group, depression was } \\
\text { associated with poorer QoL on both physical and } \\
\text { mental components ( } 48.6 \text { vs } 30.3 \text { and } 57.5 \text { vs } 33.7 \text {, } \\
\text { respectively, } p s<0.01) \text {. Anxiety was also associated } \\
\text { with poorer QoL on both physical and mental } \\
\text { components (54.8 vs } 30.8 \text { and } 62.7 \text { vs } 40.5, p s<0.01 \text { ) }\end{array}$ \\
\hline $\begin{array}{l}\text { McCormick } \\
\text { et al. }{ }^{41}\end{array}$ & $\begin{array}{l}44 \text { adults } \\
\text { with asthma }\end{array}$ & $\begin{array}{l}\text { Cross-sectional, recruited from } \\
\text { secondary care }\end{array}$ & $\begin{array}{l}\text { Maladaptive coping (based on the } \\
\text { transactional stress models of health) } \\
\text { assessed with the Social Problem } \\
\text { Solving Inventory Revised: Short Form }\end{array}$ & Mini-AQLQ & $\begin{array}{l}\text { Controlling for variance associated with gender, age, } \\
\text { and income, people with higher impulsive-careless } \\
\text { scores scored lower on QoL }(\beta=0.79, p<0.01) \text {. } \\
\text { Problem-solving style was the only significant } \\
\text { independent predictor of QoL }\end{array}$ \\
\hline $\begin{array}{l}\text { Miedinger } \\
\text { et al. } .^{37}\end{array}$ & $\begin{array}{l}60 \text { adult participants } \\
\text { with } \\
\text { occupational asthma }\end{array}$ & $\begin{array}{l}\text { Cross-sectional, people } \\
\text { recruited after being evaluated } \\
\text { for a permanent disability } \\
\text { indemnity }\end{array}$ & $\begin{array}{l}\text { Primary Care Evaluation of Mental } \\
\text { Disorders-PRIME-MD; Psychiatric } \\
\text { Symptoms Index }\end{array}$ & $\begin{array}{l}\text { AQLQ \& the St-Georges } \\
\text { Respiratory Questionnaire }\end{array}$ & $\begin{array}{l}\text { Significant medium-to-high correlations between the } \\
\text { PSI and AQLQ ( } r=-0.619) ; \text { having any mood or } \\
\text { psychiatric disorder according to PRIME-MD showed } \\
\text { significant medium correlations with all subscales of } \\
\text { the AQLQ ( } r=0.417 \text { for any psychiatric disorder and } \\
\text { composite score of AQLQ) }\end{array}$ \\
\hline $\begin{array}{l}\text { Nishimura } \\
\text { et al. } .^{55}\end{array}$ & $\begin{array}{l}162 \text { adult patients } \\
\text { with mild-to-severe } \\
\text { well- } \\
\text { controlled asthma }\end{array}$ & $\begin{array}{l}\text { Cross-sectional, consecutive } \\
\text { patients recruited from an } \\
\text { outpatient secondary } \\
\text { care clinic }\end{array}$ & HADs and presence of dyspnoea & $\begin{array}{l}\text { Living with asthma } \\
\text { questionnaire (LVAQ) } \\
\text { and SF-36 }\end{array}$ & $\begin{array}{l}\text { Having anxiety or depression according to HADs } \\
\text { scores showed mild but significant correlations with } \\
\text { both QoL questionnaires (scores ranging from } 0.31 \text { to } \\
0.60 \text { ). Severity of dyspnoea was also associated with } \\
\text { both, with correlation scores ranging from } 0.22 \text { to } 0.56\end{array}$ \\
\hline Oga et al. ${ }^{54}$ & $\begin{array}{l}87 \text { adult Patients } \\
\text { with stable asthma }\end{array}$ & $\begin{array}{l}\text { Longitudinal, recruited from an } \\
\text { outpatient secondary care } \\
\text { asthma clinic } 6 \text { months after } \\
\text { treatment and follow-up } \\
5 \text { years }\end{array}$ & HADs & AQLQ & $\begin{array}{l}\text { Changes in HADs scores were significantly correlated } \\
\text { with changes in AQLQ on both anxiety and depression } \\
\text { scales }(r=-0.6,6<0.01 \text { and } r=-0.5, p<0.01 \\
\text { respectively), but not changes in physiological } \\
\text { measures. HADs scores overall remained similar over } \\
\text { the 5-year follow-up period }\end{array}$ \\
\hline $\begin{array}{l}\text { Oguzturk } \\
\text { et al. } .^{21}\end{array}$ & $\begin{array}{l}70 \text { patients (with } \\
\text { stable asthma and } \\
\text { aged }>60 \text { years) and } \\
40 \text { age-matched } \\
\text { controls }\end{array}$ & $\begin{array}{l}\text { Cross-sectional, recruited from } \\
\text { a secondary care respiratory } \\
\text { clinic (matched controls were } \\
\text { recruited from local mosques) }\end{array}$ & HADs & AQLQ & $\begin{array}{l}\text { Patients with earlier-onset asthma (duration }>8 \text { years) } \\
\text { had lower QoL scores than those with recent-onset } \\
\text { asthma. Anxiety and depression were significant } \\
\text { predictors of AQLQ scores, anxiety accounted for } 49 \% \\
\text { and depression for } 41 \% \text { of the total score }\end{array}$ \\
\hline Pate et al. ${ }^{46}$ & $\begin{array}{l}18,856 \text { people } \\
\text { with asthma }\end{array}$ & $\begin{array}{l}\text { Cross-sectional, sample } \\
\text { recruited from wider telephone } \\
\text { population study of } 39,321 \\
\text { (BRFFS sample) }\end{array}$ & $\begin{array}{l}\text { Additional chronic conditions, BMI, } \\
\text { presence of depression }\end{array}$ & $\begin{array}{l}\text { General Health, Activity } \\
\text { Limitation, Physical/Mental } \\
\text { Health Impairment (Yes/No } \\
\text { Questions) }\end{array}$ & $\begin{array}{l}\text { Having additional conditions }(P R=4.26) \text {, depression } \\
(\mathrm{PR}=1.97) \text {, as well as either underweight }(\mathrm{PR}=1.82) \text {, } \\
\text { overweight ( }(\mathrm{PR}=1.19) \text {, or obese }(\mathrm{PR}=1.76) \mathrm{BMl} \text { were } \\
\text { all significantly associated with } \geq 14 \text { days of activity } \\
\text { limitation, as well as self-rated fair/poor health }\end{array}$ \\
\hline
\end{tabular}


Table 1 continued

\begin{tabular}{|c|c|c|c|c|c|}
\hline Study & Sample & Study design and recruitment & Predictor & QoL measurement & Findings-summary \\
\hline $\begin{array}{l}\text { Powell } \\
\text { et } \text { al. }^{49}\end{array}$ & $\begin{array}{l}218 \text { pregnant } \\
\text { women with asthma } \\
\text { and rhinitis }\end{array}$ & $\begin{array}{l}\text { Cross-sectional, recruited from } \\
\text { an ante-natal clinic }\end{array}$ & $\begin{array}{l}\text { Rhinitis was assessed using a visual } \\
\text { analogue scale, Six Item Short-Form } \\
\text { State Trait Anxiety Inventory }\end{array}$ & AQLQ-M & $\begin{array}{l}\text { QoL scores were predicted by the presence of rhinitis, } \\
\text { anxiety, and prior history of rhinitis (medians } 0.63 \text { vs } \\
1.06, p<0.01 \text { for pregnant women with asthma, with } \\
\text { and without current rhinitis) }\end{array}$ \\
\hline $\begin{array}{l}\text { Sandez } \\
\text { et al. }{ }^{24}\end{array}$ & $\begin{array}{l}40 \text { adult patients } \\
\text { with near- } \\
\text { fatal asthma }\end{array}$ & $\begin{array}{l}\text { Cross-sectional, recruited from } \\
\text { an outpatient asthma clinic } \\
\text { (secondary care) }\end{array}$ & $\begin{array}{l}\text { Beck's Depression Inventory and the } \\
\text { Panic-Fear Scale of the Asthma } \\
\text { Symptom Checklist }\end{array}$ & $\begin{array}{l}\text { SF-36 (MCS and PCS } \\
\text { components) }\end{array}$ & $\begin{array}{l}\text { Panic-Fear (PF) and age accounted for } 22.8 \% \text { of } \\
\text { variance in PCS and depressive symptoms accounted } \\
\text { for } 48.6 \% \text { of the variance in MCS. PF was significantly } \\
\text { and negatively correlated with both MCS and PCS ( } r= \\
-0.53 \text { and } r=-0.36 \text {, respectively, } p s<0.05) \text {. } \\
\text { Depressive symptoms were only significantly } \\
\text { correlated with MCS }(r=-0.69, p<0.05)\end{array}$ \\
\hline $\begin{array}{l}\text { Strine } \\
\text { et al. }\end{array}$ & $\begin{array}{l}18,856 \text { people } \\
\text { with asthma }\end{array}$ & $\begin{array}{l}\text { Cross-sectional, sample } \\
\text { recruited from wider telephone } \\
\text { population study of } 39,321 \\
\text { (BRFFS sample) }\end{array}$ & $\begin{array}{l}\text { PHQ-8, self-report diagnosis of } \\
\text { depression, BMI }\end{array}$ & $\begin{array}{l}\text { General Health, Activity } \\
\text { Limitation, Physical/Mental } \\
\text { Health Impairment (Yes/No } \\
\text { Questions) }\end{array}$ & $\begin{array}{l}\text { Among adults with asthma, people with current } \\
\text { depression were significantly more likely than those } \\
\text { without depression to report more mean numbers of } \\
\text { days in the past } 30 \text { days of physical distress }(\mathrm{OR}=4.7) \text {, } \\
\text { mental distress }(\mathrm{OR}=14.3) \text {, activity limitations }(\mathrm{OR}= \\
7.0) \text {, depressive symptoms }(\mathrm{OR}=23.6) \text {, anxiety } \\
\text { symptoms }(\mathrm{OR}=9.8) \text {, insufficient sleep (OR }=6.3) \text {, } \\
\text { pain }(\mathrm{OR}=6.0) \text {, and fatigue }(\mathrm{OR}=13.3) \text {. There was a } \\
\text { dose response relationship between depression } \\
\text { severity and the mean number of days of physical } \\
\text { distress, mental distress, depressive symptoms, } \\
\text { fatigue, anxiety symptoms, and activity limitations. } \\
\text { Those with current depression were also significantly } \\
\text { more likely to have an obese BMI }\end{array}$ \\
\hline Tay et al. ${ }^{48}$ & $\begin{array}{l}90 \text { adult patients } \\
\text { with difficult asthma }\end{array}$ & $\begin{array}{l}\text { Cross-sectional, consecutive } \\
\text { patients recruited from a } \\
\text { difficult asthma clinic }\end{array}$ & $\begin{array}{l}\text { Having one of the eight } \\
\text { comorbidities: allergic rhinitis, chronic } \\
\text { rhinosinusitis, gastro-oesophageal } \\
\text { reflux disease, obesity, obstructive } \\
\text { sleep apnoea, anxiety or depression, } \\
\text { dysfunctional breathing, and vocal } \\
\text { cord dysfunction }\end{array}$ & AQLQ & $\begin{array}{l}\text { BMI was an independent predictor of poor QoL ( } \beta= \\
-0.05, p<0.01) \text {. Dysfunctional breathing predicted } \\
\text { poor QoL }(\beta=-0.73, p<0.05) \text {, as did vocal cord } \\
\text { dysfunction }(\beta=-0.78, p<0.05) \text {. On univariate } \\
\text { analysis, BMI, VCD, DB, OSA, and GORD were } \\
\text { significantly associated with decreased QoL }\end{array}$ \\
\hline $\begin{array}{l}\text { Urbstonaitis } \\
\text { et al. }{ }^{47}\end{array}$ & $\begin{array}{l}5857 \text { late midlife } \\
\text { adults with asthma }\end{array}$ & $\begin{array}{l}\text { Cross-sectional, sample } \\
\text { recruited from wider telephone } \\
\text { population study of } 39,321 \\
\text { (BRFFS sample) }\end{array}$ & $\begin{array}{l}\text { BMI, presence of respiratory } \\
\text { comorbidity }\end{array}$ & $\begin{array}{l}\text { General Health, Activity } \\
\text { Limitation, Physical/Mental } \\
\text { Health Impairment (Yes/No } \\
\text { Questions) }\end{array}$ & $\begin{array}{l}\text { Respiratory comorbidity was significantly associated } \\
\text { with poor QoL on all dimensions and independent of } \\
\text { asthma control }(\mathrm{OR}=17) \text {. People with poorly } \\
\text { controlled asthma were more likely to have an obese } \\
\text { BMI. The combination of poor control and obese BMI } \\
\text { was significantly associated with poorer general } \\
\text { health }(\mathrm{OR}=2.3)\end{array}$ \\
\hline $\begin{array}{l}\text { Vasquez } \\
\text { et al. }{ }^{23}\end{array}$ & $\begin{array}{l}76 \text { adults } \\
\text { with asthma }\end{array}$ & $\begin{array}{l}\text { Cross-sectional, recruited from } \\
\text { a secondary care pneumology } \\
\text { department. }\end{array}$ & $\begin{array}{l}\text { Cognitive Depression Index (subscale } \\
\text { of the Beck Depression Inventory); } \\
\text { Trait Subscale of the State-Trait } \\
\text { Anxiety Scale; the Twenty-ltem } \\
\text { Toronto Alexithymia Scale-this has } \\
\text { three dimensions: DIF, DDF, and EOT }\end{array}$ & $\begin{array}{l}\text { SF- } 36 \text { and The St George's } \\
\text { Respiratory Questionnaire to } \\
\text { measure disease-specific } \\
\text { impairment }\end{array}$ & $\begin{array}{l}\text { Trait anxiety, depression scores, and alexithymia were } \\
\text { included in a regression model that explained } \\
\text { between } 23 \% \text { and } 39 \% \text { of variance in QoL. Depression } \\
\text { was a significant independent predictor and } \\
\text { associated with all subscales of the SF-36, as well as all } \\
\text { the subscales of the SGRQ }\end{array}$ \\
\hline $\begin{array}{l}\text { Vortmann } \\
\text { and Eisner }\end{array}$ & $\begin{array}{l}843 \text { adult patients } \\
\text { with severe asthma }\end{array}$ & $\begin{array}{l}\text { Cross-sectional, recruited } \\
\text { patients who were hospitalized } \\
\text { for asthma in the previous } \\
4 \text { years. }\end{array}$ & $\begin{array}{l}\text { BMI from self-reported height and } \\
\text { weight, atopic history; Center for } \\
\text { Epidemiologic Studies } \\
\text { Depression Scale }\end{array}$ & $\begin{array}{l}\text { Marks Asthma QoL } \\
\text { Questionnaire and the SF-12 } \\
\text { and daily activity restriction }\end{array}$ & $\begin{array}{l}\text { Compared to normal BMI, general physical health was } \\
\text { significantly worse in those with obese BMI (mean } \\
\text { score decrement of }-6.31 \text { ) and overweight BMI (mean } \\
\text { score decrement }-2.42 \text { ). Asthma-specific quality of life } \\
\text { was significantly worse in the underweight group } \\
\text { (mean score difference } 8.66 \text { points) and obese group } \\
\text { ( } 4.51 \text { points). People with obese BMI also had a higher } \\
\text { number of restricted activity days ( } 5.05 \text { days more). } \\
\text { Obese patients had significantly higher risk of } \\
\text { depressive symptoms. Depression was found to be a } \\
\text { significant mediator of the relationship between } \\
\text { obesity and health status, asthma QoL, and restricted } \\
\text { activity days }\end{array}$ \\
\hline $\begin{array}{l}\text { Wijnhoven } \\
\text { et al. }{ }^{25}\end{array}$ & $\begin{array}{l}395 \text { patients with } \\
\text { asthma, aged } 40-75\end{array}$ & $\begin{array}{l}\text { Cross-sectional, participants } \\
\text { recruited from general practice }\end{array}$ & $\begin{array}{l}\text { Presence or absence of: diabetes } \\
\text { mellitus, hypertension, cardiac } \\
\text { disease, cerebrovascular disease, } \\
\text { musculoskeletal disease, and } \\
\text { malignancies and asked if they had } \\
\text { any other chronic condition. } \\
\text { Comorbidity was defined as (1) the } \\
\text { presence of comorbidity; (2) number } \\
\text { of comorbid conditions; (3) presence } \\
\text { of specific comorbidity }\end{array}$ & $\begin{array}{l}\text { Disease-specific instrument: } \\
\text { Quality of Life in Respiratory } \\
\text { Illness Questionnaire; generic } \\
\text { instrument: the Dutch version } \\
\text { of the Nottingham Health } \\
\text { Profile (NHP) }\end{array}$ & $\begin{array}{l}\text { Having one or more comorbidities was significantly } \\
\text { associated with poorer asthma-specific } \mathrm{Q} \text { oL }(\mathrm{OR}= \\
2.08 \text { ) and poorer general } \mathrm{QoL}(\mathrm{OR}=2.96) \text {. Poorest } \mathrm{QoL} \\
\text { was found in patients with more than one comorbid } \\
\text { condition (OR }=4.77) \text {. Cardiac disease and } \\
\text { hypertension were significantly associated with poor } \\
\text { disease-specific QoL in asthma, and musculoskeletal } \\
\text { disorders were most strongly associated with poor } \\
\text { general QoL }\end{array}$ \\
\hline $\begin{array}{l}\text { Yilmaz } \\
\text { et al. }^{31}\end{array}$ & $\begin{array}{l}97 \text { adult patients } \\
\text { with asthma and } 97 \\
\text { healthy controls }\end{array}$ & $\begin{array}{l}\text { Cross-sectional, recruited from } \\
\text { a secondary care outpatient } \\
\text { chest disease clinic }\end{array}$ & $\begin{array}{l}\text { SCID-II (structured method of } \\
\text { interview, according to the DSM-III-R } \\
\text { to diagnose axis II personality } \\
\text { disorders) }\end{array}$ & SF-36 & $\begin{array}{l}\text { People with asthma and personality disorders had } \\
\text { significantly lower QoL scores than people with } \\
\text { asthma and no personality disorders. This was } \\
\text { significant for physical role functioning ( } 42.68 \text { vs } 62.50 \text {, } \\
p<0.05) \text {, general health }(38.56 \text { vs } 53.60, p<0.01) \text {, and } \\
\text { mental health ( } 53.75 \text { vs } 65.55, p<0.01) \text {. All } \\
\text { physiological measures (FEV, severity of asthma, } \\
\text { disease duration, etc.) were not significantly different } \\
\text { between people with or without personality disorders }\end{array}$ \\
\hline
\end{tabular}

physical condition (such as rhinitis, cardiovascular disease, diabetes, etc.). Having more than one co-existing condition or psychological factor impacted overall QoL even more substantially. Results for each of the aspects found are presented below.

\section{Psychological factors}

Within this first theme, four subthemes were generated. These comprised 'anxiety and depression', 'other mental health conditions', 'emotional regulation', and 'illness representations'.
Anxiety and depression were notably the most commonly considered factors $(n=30)$. A high prevalence of people with asthma showed symptoms of or clinical diagnoses of anxiety or depression, which appeared to play a key role in understanding the relationship between asthma and QoL. Overall, having a diagnosis of anxiety or depression was associated with poorer QoL across all dimensions (e.g. activity limitation, physical or mental wellbeing, social or role functioning, etc.), as well as health perceptions. ${ }^{24,36,46,50,54}$ In particular, one study (of undergraduate students aged 18-25 years, with childhood-onset asthma) found 
Table 2. Themes, subthemes, and descriptions

\begin{tabular}{|c|c|c|}
\hline Theme & Subtheme & Description \\
\hline & $\begin{array}{l}\text { Other mental health } \\
\text { conditions }\end{array}$ & $\begin{array}{l}\text { Panic disorder with or without agoraphobia, }{ }^{24,38,44,57} \text { personality disorders, }{ }^{31} \text { alexithymia, }{ }^{23} \\
\text { somatization, }{ }^{38} \text { mood disorders, }{ }^{12,40,57} \text { schizophrenia, eating disorders, substance use } \\
\text { disorders, }{ }^{38} \text { and general occurrence of any psychiatric disorder }{ }^{12,17}\end{array}$ \\
\hline & Emotion regulation & Negative affect ${ }^{28,39}$ or coping $^{41,51}$ \\
\hline Physical health factors & Physical health conditions & $\begin{array}{l}\text { Diabetes, }{ }^{25,48} \text { obesity, }{ }^{48} \text { hypertension, }{ }^{25,39} \text { gastro-oesophageal reflux disorder, }{ }^{48} \text { rhinitis }^{48,49} \\
\text { vocal cord dysfunction }^{48} \text { sleep apnoea, }{ }^{48} \text { musculoskeletal disorders, }{ }^{25,39} \text { arthritis, }{ }^{39,52} \text { heart } \\
\text { disease, }{ }^{25} \text { stroke, }{ }^{39,52} \text { cancer, }{ }^{39,52} \text { osteoporosis, }{ }^{52} \text { dysfunctional breathing }{ }^{48} \text { headaches }{ }^{39} \text { and } \\
\text { allergic status, }{ }^{27,39} \text { or the presence of additional chronic conditions }{ }^{25,27,33,34,36,39,46-49,52,53,56,59}\end{array}$ \\
\hline
\end{tabular}

that anxiety was significantly associated with asthma QoL, as was the interaction between anxiety and depression, ${ }^{32}$ while others found that generally anxiety and depression both predicted worse QoL independently ( refs $^{12,29,33,38,42,44,56,60}$ ). One study found that the average asthma-related QoL scores for people with asthma and depression were 1.4 times lower compared to people with asthma and no depression. ${ }^{33}$ Having current depression or anxiety was associated with worse QoL than was having a lifetime diagnosis; this was in turn was greater than having no depression or anxiety. ${ }^{45}$ Having a history of major depression was also significantly associated with worse physical and mental functioning, compared to those with asthma and no depression. ${ }^{38}$ There was considerable variability across variance explained, with depression found to account for between $3 \%{ }^{40}$ and $56 \%{ }^{30}$ of the variance in QoL, whereas anxiety was found to account for between $2 \%{ }^{40}$ and $68 \% .^{21}$

In contrast, one study found that having either a depressive or an anxiety disorder significantly impacted asthma QoL but having both was not significantly different than only having one, ${ }^{40}$ which is dissonant with other studies. Another study of 90 people with difficult asthma found that having anxiety or depression had no significant effect on QoL. ${ }^{48}$ In addition, although depression was associated with poorer QoL, it did not inflate the relationship between asthma severity and QoL. ${ }^{29}$ All other studies were significant but showed only small-to-moderate effect sizes. Having a full clinical diagnosis of anxiety or depression was not significantly worse (in terms of QoL) than having only some symptoms of anxiety and depression.

Studies also considered the impact of anxiety and depression on specific subdomains of QoL and asthma-specific QoL. Having anxiety was not associated with physical functioning, mental health or health perception, ${ }^{38}$ or the physical component of QoL. ${ }^{20}$ Depression, however, was associated with significantly poorer QoL on physical dimensions and activity limitation, ${ }^{20,21,23,30,38,45,53,55,58}$ although one study found significant results only for participants with uncontrolled asthma. ${ }^{22}$ In relation to asthma-specific QoL, depression and anxiety were significantly associated with decreased asthma-specific QoL. 17,21,23,27,28,32,33,36,37,40,50,54,55,58,61

Nine studies looked at other mental health conditions, such as panic disorder with or without agoraphobia, ${ }^{24,38,44,57}$ personality disorders, ${ }^{31}$ alexithymia, ${ }^{23}$ somatization, ${ }^{38}$ mood disorders, ${ }^{12,40,57}$ schizophrenia, eating disorders, substance use disorders, ${ }^{38}$ and general occurrence of any psychiatric disorder. ${ }^{12,17}$ The results in this subtheme were mixed, but overall they suggest that the presence of an additional mental health condition is significantly associated with a decrease in QoL in patients with asthma. ${ }^{12,17}$ Panic disorder was also shown to be both significantly ${ }^{24}$ and nonsignificantly ${ }^{57}$ associated with poorer mental and physical components of QoL. Alexithymia in people with asthma was not associated with poorer QoL. ${ }^{23}$ Having asthma and a personality disorder was associated with lower general QoL, ${ }^{31}$ as well as lower scores for physical health, vitality, pain, general health, social function, mental health, and emotional role (physical function was not significant). This association was not found for people without asthma, suggesting that it is the combination of conditions (asthma and co-existing mental health conditions) that may lead to the negative impact on QoL. ${ }^{31}$

The emotion regulation subtheme included studies that explored the relationship between emotional states, negative affect (not related to anxiety, depression, or other mental health conditions), or coping and QoL in people with asthma. QoL in asthma was found to be influenced by affect and a predisposition to negative states, as found by four studies. ${ }^{28,39,41,51}$ For instance, a model of age, gender, negative affect, and medical problems accounted for $20 \%$ of symptoms and $23 \%$ of activity limitation. ${ }^{39}$ This was supported by findings that negative mood is associated with poor scores on both the mental and physical components of the Asthma Quality of Life Questionnaires (AQLQ), ${ }^{28}$ as well as a positive correlation between active coping and asthma QoL. ${ }^{51}$ Despite heterogeneity, the impaired QoL was associated with impulsive-careless coping ${ }^{41}$ and avoidant coping. ${ }^{51}$ Overall, the presence of psychological distress seemed to affect people with asthma more than people without asthma in terms of QoL.

Illness-related cognitions are people's patterns of beliefs about the characteristics of their conditions, which in turn influence their appraisal of severity and can determine future behaviours. ${ }^{63} \mathrm{~A}$ number of illness-related cognitions and perceptions significantly predicted QoL in seven studies. ${ }^{26,34,37,42,43,51,60}$ For instance, asthma self-efficacy ${ }^{42}$ was positively associated with QoL. However, decreased QoL was significantly predicted by a series of varied illness perceptions: subjective illness severity, uncertainty in illness, illness intrusiveness, ${ }^{43}$ perceived disability, ${ }^{60}$ health beliefs and attitudes, ${ }^{34}$ perceived severity, ${ }^{34}$ level of confidence or selfefficacy in managing asthma, ${ }^{51}$ satisfaction with illness, ${ }^{51}$ anxiety sensitivity for physical concerns, ${ }^{39}$ and satisfaction with life. ${ }^{37}$ In addition, a model of subjective and objective illness severity 
accounted for $24 \%$ of the variance in QoL, further supporting the effect of illness perceptions on QoL. ${ }^{34}$

Physical health factors

Two subthemes were generated in the physical health factors theme: additional physical conditions and BMI.

Ten papers examined additional physical conditions in relation to QoL in asthma; ${ }^{25,27,34,39,46-49,52,53}$ most only referred to 'comorbidity' or 'medical problems' as a measure of frequency of additional conditions. ${ }^{34,36,39}$ Some studies looked at both general and individual co-existing conditions ${ }^{25,48,52}$ and others counted chronic conditions but did not include them in further analyses. $^{33,36,56,59}$ Of the ones that did explore individual conditions, the highest impact seemed to be provoked by musculoskeletal conditions. ${ }^{25}$ Similarly, statistically and clinically significant decreases in activity levels were also found for people with asthma and multimorbid conditions. ${ }^{52}$ Other conditions investigated included respiratory conditions, ${ }^{47}$ diabetes, ${ }^{25,48}$ obesity $^{48}$ hypertension, ${ }^{25,39}$ gastro-oesophageal reflux disorder, ${ }^{48}$ rhinitis, ${ }^{48,49}$ vocal cord dysfunction, ${ }^{48}$ sleep apnoea, ${ }^{48}$ musculoskeletal disorders, ${ }^{25,39}$ arthritis, ${ }^{39,52}$ heart disease, ${ }^{25}$ stroke, ${ }^{39,52}$ cancer, ${ }^{39,52}$ osteoporosis, ${ }^{52}$ dysfunctional breathing, ${ }^{48}$ headaches, $^{39}$ and allergic status. ${ }^{27,39}$ The consensus was that having an additional physical condition significantly decreased QoL in asthma, the effect being amplified with the addition of further conditions.

Eleven papers exploring BMI found that it consistently influenced QoL for people with asthma both directly as a multimorbid factor and indirectly by increasing the chance of additional conditions and activity limitation. ${ }^{25,26,28,29,35,42,44,45,48,56,59}$ In particular, one study found that generic health status decreased for overweight and obese patients with asthma. People with asthma with obesity had on average 5.05 more restricted activity days than people without obesity or without asthma. ${ }^{35}$ Other studies found that increased $\mathrm{BMI}$ was an independent factor in predicting poorer $\mathrm{QoL}^{48}$ and that QoL was two times worse in overweight and three times worse in obese people with asthma. ${ }^{59}$ In contrast, one study found that overweight BMI made no difference; however, being obese did. ${ }^{27}$ Almost $1 / 2$ of obese patients and $25 \%$ overweight patients had problems with mobility, pain, discomfort, self-care, and usual activities (compared to $<15 \%$ people with asthma of normal weight). ${ }^{26}$

\section{Multifactorial aspects}

Seven studies included statistical analyses to explore potential mechanisms for the relationship between asthma QoL and additional physical conditions, BMI, and psychological factors. ${ }^{17,35,42,45,50,56,59}$ Results from studies in this group are complex, indicating that people with asthma are at a higher risk of adverse outcomes (such as exacerbated symptoms or decreased QoL) if they also have a high BMI and depression. ${ }^{35,42,56,59}$ People with current depression and asthma are more likely to be obese and 3.9 times more likely to report fair or poor general health. ${ }^{45} \mathrm{~A}$ few of these studies have explored the relationship between these factors further. For example, people with asthma and obesity were more likely to have additional physical comorbidities and poorer QoL. ${ }^{59}$ Significant increases in major depression were associated with dyspnoea, ${ }^{50}$ and depression and perceived control of asthma significantly mediated between BMI and QoL. ${ }^{35}$ Higher BMI has also been associated with worse asthma-specific self-efficacy, which was in turn associated with decreased QoL. ${ }^{42}$

\section{DISCUSSION}

The aim of the present review was to synthesise the literature exploring health and psychological factors that influence QoL in adults with asthma. Previous evidence shows that QoL is generally lower in people with asthma and compounded by poor asthma control and severity. ${ }^{13}$ The narrative synthesis in the present study builds on this by identifying three themes, encompassing a number of factors that substantially explain further impairment in QoL for people with asthma. These were not limited to individual components but also combinations of co-existing conditions, risk factors, and health and psychological factors, which consistently showed a negative impact on QoL.

Anxiety and depression were the most commonly reported psychological factors associated with impaired QoL, but effects were also found for other mental health conditions, illness representations, and emotion regulation. These results are generally consistent with previous research showing not only that among people with asthma there are more people with depression than without ${ }^{8}$ but also with an increase in depression, the risk of asthma increased. ${ }^{64}$ Although the relationship between anxiety and depression and asthma-specific QoL were not further considered in the primary sources, they point towards either a link with activity limitation or a cumulative impact of the interaction between these psychological factors, which in turn affect the QoL of people with asthma. In addition, it is argued that people with asthma use more emotion-focused, and generally maladaptive, coping strategies, such as avoidance. ${ }^{65}$ Despite this, psychotherapy, such as cognitive-behavioural therapy and counselling has had limited effectiveness in improving asthma outcomes. ${ }^{66}$

Physical health factors, such as high BMI and co-occurring health conditions, were extremely common in people with asthma, consistent with existing literature. ${ }^{16}$ This affects QoL both directly and indirectly, affecting self-management and illness perceptions. As such, non-pharmacological treatments such as lifestyle change and activity promotion could prove effective. For instance, a higher proportion of people with asthma seem to have overweight or obese $\mathrm{BMI}^{67}$ and weight loss intervention studies have been associated with improvements in asthma symptoms. ${ }^{68}$

One of the fundamental components of reduced QoL is activity limitation, which is especially relevant to people with asthma, with or without additional conditions or psychological risk factors. This has been widely acknowledged by previous research, to the extent that it has been included as one of the components of asthma-related QoL measures, such as the AQLQ. ${ }^{69}$ Furthermore, it is not surprising that decreased QoL in adults with asthma is associated with depression or high BMI, both of which have been consistently associated with activity limitation (e.g. refs ${ }^{70,71}$ ). In addition, depression was found to affect QoL on the physical components as well as the mental ones, which has interesting implications for future research and clinical practice.

It is important to note the high prevalence of anxiety, depression, and chronic conditions, despite frequent exclusion of comorbid psychiatric conditions. This was found throughout the included papers and is consistent with previous research (e.g. refs $\left.{ }^{8,16}\right)$. This does not only mean that psychological and health factors significantly add to the burden of living with asthma but also that the occurrence of psychological dysfunction and health risk factors seem to be common in people with asthma. In addition, the complex nature of patients with chronic diseases such as asthma, with factors interacting, adds to the negative experience of living with asthma. Results are similar to previous meta-analyses and reviews, ${ }^{8,72}$ pointing towards conclusive evidence that additional factors (physical or psychological) decrease QoL and functionality in asthma. Finally, these effects were consistent, regardless of the measure of QoL used (asthma specific, health related, or general). This suggests that the identified factors may affect people with asthma more than people without asthma or that the cumulative impact of comorbidities is greater than arithmetically assumed.

The quality of the present review needs to be discussed in relation to the methodology and robustness of the synthesis, 
determined by the quantity and quality of individual studies included. ${ }^{73}$ The quality assessment identified that most studies were of a reasonable quality overall, although all papers had one or two elements that were of a slightly lower quality (this included aspects such as recruitment from only one hospital reducing generalizability or self-report vs objective measurement of weight for BMI calculations). However, this was not problematic for the purposes of this review as the focus was to identify potential factors considered in research rather than classify the methodological quality used to measure their impact on QoL. In addition, the search terms in this review could have limited the number and kind of studies included. For instance, not every potential comorbid condition was listed. This could be a focus for future research. Socio-demographic factors were not included, which can be considered a limitation; however, the breadth of the area was deemed too much for the scope of the present review and could also be the focus of future research. The majority of included studies were observational and as such could not be used to determine causal mechanisms. However, the aim of this review was only to identify potential factors involved in decreased QoL in asthma, rather than build a causal model. Similarly, the impact of individual factors was not measured and could be explored in future research.

A strength of the present review is that it uses a novel approach to QoL in asthma, by systematically taking into account additional aspects that influence the experience of living with asthma and impact QoL. Results suggest both a direct association of the identified aspects, as well as indirectly through interactions with other aspects of living with asthma, such as overarching illness perceptions and activity limitation. The present review emphasizes some interesting and novel findings for asthma and QoL research. Three main implications for future research and practice are proposed. First, for future research, the findings of this review should be used to further explore and understand the factors impacting QoL in people with asthma. It is crucial to explore the needs and experience of patients with complex medical problems, in order to unpick the different factors impacting on QoL. Second, the results are relevant for practitioners, particularly in primary care, as they draw attention to the prevalence of various physical and mental health factors that can interact and affect asthma outcomes. This could influence training or guidelines on potential factors to consider during appointments and consultations. Finally, most current non-pharmacological interventions for patients with chronic conditions tend to overlook the complex needs of patients in a multimorbidity context. As such, it is suggested that future intervention development should use a personalized, tailored approach that aims to address the needs of patients with complex medical problems in the wider context of their experience of living with asthma.

This review demonstrates that the themes and factors identified through inductive narrative synthesis illustrate that QoL in asthma cannot be determined in a simplistic way. The findings suggest a complex experience in living with asthma, one that has a stronger impact on QoL than the sum its of parts. People with asthma and their QoL cannot be viewed separately from the psychological and other health elements that they experience. Future research is encouraged to take a function-oriented approach to QoL in asthma, including management of multimorbid conditions when planning studies; clinical practice should also acknowledge the additional and complex needs of people with asthma by offering relevant, person-based tailored interventions.

\section{METHOD}

Search strategy

The initial search was carried out in April 2017 and was updated in January 2019. Databases searched included MEDLINE, EMBASE,
PsycINFO, the Cochrane Library, and Web of Science. Search terms used comprised a combination of the following key terms: asthma (MESH term), psychological/psychosocial and factor/determinant/ predictor, comorbid, multimorbid, anxiety, depression, illness perception, illness cognition, illness representation, locus of control, self-efficacy, risk factor, quality of life, health-related quality of life, wellbeing, distress, health status, burden. In addition, a hand search of all the references of included papers was performed as well as a grey literature search on Google Scholar.

\section{Study selection}

Studies were included if they investigated psychological or physical health factors and included QoL in adults with asthma as primary or secondary outcome. Psychological factors were considered any modifiable factors, including thoughts, beliefs, attitudes, or emotions of people with asthma, as well as the presence of any co-occurring mental health condition. Physical health factors were defined as any physical comorbid or multimorbid condition or risk factor. These were chosen to allow as much inclusivity as possible and to reflect the exploratory nature of this review. Intervention studies were excluded, as they rarely considered the impact of health or psychological factors on QoL but rather investigated how interventions improved asthma outcomes. Studies were excluded if they were conference abstracts, reviews, or not primary research or the full text not in English, German, or Spanish language.

\section{Data extraction and quality appraisal}

Data extracted comprised authors, year of publication, study sample, predictors, QoL measurement (outcome), and findings. The AXIS tool ${ }^{74}$ was used to assess the quality of included papers. This contains questions on study design, sample size justification, target population, sampling frame, sample selection, measurement validity and reliability, and overall methods and does not offer a numerical scale. No papers were excluded or weighted based on the quality assessment.

\section{Data synthesis}

Owing to heterogeneity of QoL measures and the range of variables used in the included studies, narrative synthesis was used to describe and group similar findings, explore patterns identified in the literature, and develop a narrative account of the results. ${ }^{73}$ This is an approach to systematic reviews involving the synthesis of findings from multiple sources and relies primarily on word and text to summarise the findings.

All data generated or analysed during this study are included in this published article.

\section{Reporting summary}

Further information on research design is available in the Nature Research Reporting Summary linked to this article.

Received: 29 April 2019; Accepted: 24 September 2019; Published online: 21 October 2019

\section{REFERENCES}

1. World Health Organization. Chronic Respiratory Diseases - Asthma http://www. who.int/respiratory/asthma/en/ (2018).

2. ASTHMA UK. Asthma Facts and Statistics https://www.asthma.org.uk/about/ media/facts-and-statistics/ (2018)

3. Pickles, K. et al. "This illness diminishes me. What it does is like theft": a qualitative meta-synthesis of people's experiences of living with asthma. Health Expectations 21, 23-40 (2018). 
4. Goeman, D. P. \& Douglass, J. A. Understanding asthma in older Australians: a qualitative approach. Med. J. Aust. 183, S26-S27 (2005).

5. Juniper, E. F. How important is quality of life in pediatric asthma? Pediatr. Pulmonol. 24, 17-21 (1997).

6. Accordini, S. et al. The socio-economic burden of asthma is substantial in Europe. Allergy 63, 116-124 (2008).

7. Goeman, D. P. et al. Patients' views of the burden of asthma: a qualitative study. Med. J. Aust. 177, 295-299 (2002).

8. Thomas, M., Bruton, A., Moffat, M. \& Cleland, J. Asthma and psychological dysfunction. Prim. Care Respir. J. 20, 250-256 (2011).

9. Goodwin, R. D., Fergusson, D. M. \& Horwood, L. J. Asthma and depressive and anxiety disorders among young persons in the community. Psychol. Med. 34, 1465-1474 (2004).

10. Jenkins, R. et al. The national psychiatric morbidity surveys of Great Britain-strategy and methods. Psychol. Med. 27, 765-774 (1997).

11. Miles, J., Garden, G., Tunnicliffe, W., Cayton, R. \& Ayres, J. Psychological morbidity and coping skills in patients with brittle and non-brittle asthma: a case-control study. Clin. Exp. Allergy 27, 1151-1159 (1997).

12. Lavoie, K. L. et al. Are psychiatric disorders associated with worse asthma control and quality of life in asthma patients? Respir. Med. 99, 1249-1257 (2005).

13. Juniper, E. F., Guyatt, G. H., Ferrie, P. J. \& Griffith, L. E. Measuring quality of life in asthma. Am. Rev. Respir. Dis. 147, 832-832 (1993).

14. Edwards, M. R. et al. Addressing unmet needs in understanding asthma mechanisms. Eur. Respir. J. 49, 1602448 (2017).

15. Masefield, S. et al. The future of asthma research and development: a roadmap from the European Asthma Research and Innovation Partnership (EARIP). Eur. Respir. J. 49 (2017).

16. Su, X. et al. Prevalence of comorbidities in asthma and nonasthma patients: a meta-analysis. Medicine 95, e3459 (2016).

17. Adams, R. J. et al. Psychological factors and asthma quality of life: a population based study. Thorax 59, 930-935 (2004).

18. Leynaert, B., Neukirch, C., Liard, R., Bousquet, J. \& Neukirch, F. Quality of life in allergic rhinitis and asthma: a population-based study of young adults. Am. J. Respir. Crit. Care Med. 162, 1391-1396 (2000).

19. Moher, D., Liberati, A., Tetzlaff, J., Altman, D. G. \& Group, P. Preferred reporting items for systematic reviews and meta-analyses: the PRISMA statement. PLoS Med. 6, e1000097 (2009)

20. Bohmer, M. M. et al. Factors associated with generic health-related quality of life in adult asthma patients in Germany: cross-sectional study. J. Asthma 54, 325-334 (2017).

21. Oğuztürk, Ö. et al. Psychological status and quality of life in elderly patients with asthma. Psychosomatics 46, 41-46 (2005).

22. Lomper, K., Chudiak, A., Uchmanowicz, l., Rosinczuk, J. \& Jankowska-Polanska, B. Effects of depression and anxiety on asthma-related quality of life. Pneumonol. Alergol. Pol. 84, 212-221 (2016).

23. Vazquez, I. et al. The role of alexithymia in quality of life and health care use in asthma. J. Asthma 47, 797-804 (2010).

24. Sández, E. et al. Depression, panic-fear, and quality of life in near-fatal asthma patients. J. Clin. Psychol. Med. Settings 12, 175-184 (2005).

25. Wijnhoven, H. A., Kriegsman, D. M., Hesselink, A. E., de Haan, M. \& Schellevis, F. G. The influence of co-morbidity on health-related quality of life in asthma and COPD patients. Respir. Med. 97, 468-475 (2003).

26. Gonzalez-Barcala, F.-J., de la Fuente-Cid, R., Tafalla, M., Nuevo, J. \& CaamanoIsorna, F. Factors associated with health-related quality of life in adults with asthma. A cross-sectional study. Multidiscip. Respir. Med. 7, 32 (2012).

27. Coban, H. \& Aydemir, Y. The relationship between allergy and asthma control, quality of life, and emotional status in patients with asthma: a cross-sectional study. Allergy Asthma Clin. Immunol. 10, 67 (2014).

28. Ekici, A., Ekici, M., Kara, T., Keles, H. \& Kocyigit, P. Negative mood and quality of life in patients with asthma. Qual. Life Res. 15, 49-56 (2006).

29. Al-Kalemji, A. et al. Factors influencing quality of life in asthmatics - a case-control study. Clin. Respir. J. 7, 288-296 (2013).

30. Kullowatz, A., Kanniess, F., Dahme, B., Magnussen, H. \& Ritz, T. Association of depression and anxiety with health care use and quality of life in asthma patients. Respir. Med. 101, 638-644 (2007).

31. Yilmaz, A., Cumurcu, B. E., Etikan, I., Hasbek, E. \& Doruk, S. The effect of personality disorders on asthma severity and quality of life. Iran. J. Allergy Asthma Immunol. 13, 47-54 (2014).

32. Hommel, K. A., Chaney, J. M., Wagner, J. L. \& McLaughlin, M. S. Asthma-specific quality of life in older adolescents and young adults with long-standing asthma: the role of anxiety and depression. J. Clin. Psychol. Med. Settings 9, 185-192 (2002).

33. Krauskopf, K. A. et al. Depressive symptoms, low adherence, and poor asthma outcomes in the elderly. J. Asthma 50, 260-266 (2013).
34. Erickson, S. R., Christian, R. D. Jr, Kirking, D. M. \& Halman, L. J. Relationship between patient and disease characteristics, and health-related quality of life in adults with asthma. Respir. Med. 96, 450-460 (2002).

35. Vortmann, M. \& Eisner, M. D. BMI and health status among adults with asthma. Obesity (Silver Spring) 16, 146-152 (2008).

36. Mancuso, C. A., Peterson, M. G. E. \& Charlson, M. E. Effects of depressive symptoms on health-related quality of life in asthma patients. J. Gen. Intern. Med. 15, 301-310 (2000).

37. Miedinger, D., Lavoie, K. L., L'Archeveque, J., Ghezzo, H. \& Malo, J.-L. Identification of clinically significant psychological distress and psychiatric morbidity by examining quality of life in subjects with occupational asthma. Health Qua. Life Outcomes 9, 76 (2011).

38. Afari, N., Schmaling, K. B., Barnhart, S. \& Buchwald, D. Psychiatric comorbidity and functional status in adult patients with asthma. J. Clin. Psychol. Med. Settings 8 , 245-252 (2001).

39. Avallone, K. M., McLeish, A. C., Luberto, C. M. \& Bernstein, J. A. Anxiety sensitivity, asthma control, and quality of life in adults with asthma. J. Asthma 49, 57-62 (2012).

40. Lavoie, K. L. et al. What is worse for asthma control and quality of life - depressive disorders, anxiety disorders, or both? Chest 130, 1039-1047 (2006).

41. McCormick, S. P. et al. Coping and social problem solving correlates of asthma control and quality of life. Chron. Respir. Dis. 11, 15-21 (2014).

42. Lavoie, K. L. et al. Association of asthma self-efficacy to asthma control and quality of life. Ann. Behav. Med. 36, 100-106 (2008).

43. Hullmann, S. E., Eddington, A. R., Molzon, E. S. \& Mullins, L. L. Illness appraisals and health-related quality of life in adolescents and young adults with allergies and asthma. Int. J. Adolesc. Med. Health 25, 31-38 (2013).

44. Favreau, H., Bacon, S. L., Labrecque, M. \& Lavoie, K. L. Prospective impact of panic disorder and panic-anxiety on asthma control, health service use, and quality of life in adult patients with asthma over a 4-year follow-up. Psychosom. Med. 76, 147-155 (2014).

45. Strine, T. W., Mokdad, A. H., Balluz, L. S., Berry, J. T. \& Gonzalez, O. Impact of depression and anxiety on quality of life, health behaviors, and asthma control among adults in the United States with asthma, 2006. J. Asthma 45, 123-133 (2008).

46. Pate, C. A., Zahran, H. S. \& Bailey, C. M. Impaired health-related quality of life and related risk factors among US adults with asthma. J. Asthma 56, 431-439 (2018).

47. Urbstonaitis, R., Deshpande, M. \& Arnoldi, J. Asthma and health related quality of life in late midlife adults. Res. Soc. Adm. Pharm. 15, 61-69 (2019).

48. Tay, T. R. et al. Comorbidities in difficult asthma are independent risk factors for frequent exacerbations, poor control and diminished quality of life. Respirology 21, 1384-1390 (2016).

49. Powell, $\mathrm{H}$. et al. Rhinitis in pregnant women with asthma is associated with poorer asthma control and quality of life. J. Asthma 52, 1023-1030 (2015).

50. Goldney, R. D., Ruffin, R., Fisher, L. J. \& Wilson, D. H. Asthma symptoms associated with depression and lower quality of life: a population survey. Med. J. Aust. 178, 437-441 (2003).

51. Adams, R. J., Wilson, D., Smith, B. J. \& Ruffin, R. E. Impact of coping and socioeconomic factors on quality of life in adults with asthma. Respirology 9, 87-95 (2004).

52. Adams, R. J. et al. Coexistent chronic conditions and asthma quality of life: a population-based study. Chest J. 129, 285-291 (2006).

53. Deshmukh, V. M., Toelle, B. G., Usherwood, T., O'Grady, B. \& Jenkins, C. R. The association of comorbid anxiety and depression with asthma-related quality of life and symptom perception in adults. Respirology 13, 695-702 (2008).

54. Oga, T. et al. Analysis of longitudinal changes in the psychological status of patients with asthma. Respir. Med. 101, 2133-2138 (2007).

55. Nishimura, K., Hajiro, T., Oga, T., Tsukino, M. \& Ikeda, A. Health related quality of life in stable asthma: what are remaining quality of life problems in patients with well-controlled asthma? J. Asthma 41, 57-65 (2004).

56. Choi, G.-S. et al. Prevalence and risk factors for depression in korean adult patients with asthma: is there a difference between elderly and non-elderly patients? J. Korean Med. Sci. 29, 1626-1631 (2014).

57. Faye, A. D. et al. Do panic symptoms affect the quality of life and add to the disability in patients with bronchial asthma? Psychiatry J. 2015, 608351-608351 (2015).

58. Kolawole, M. S. et al. Health related quality of life and psychological variables among a sample of asthmatics in Ile-Ife South-Western Nigeria. Libyan J. Med. 6, 1-5 (2011).

59. Maalej, S. et al. Association of obesity with asthma severity, control and quality of life. Tanaffos 11, 38 (2012). 
60. Adeyeye, O. O., Adewumi, T. A. \& Adewuya, A. O. Effect of psychological and other factors on quality of life amongst asthma outpatients in Lagos, Nigeria. Respir. Med. 122, 67-70 (2017).

61. Deshmukh, V. M., Toelle, B. G., Usherwood, T., O'grady, B. \& Jenkins, C. R The association of comorbid anxiety and depression with asthma-related quality of life and symptom perception in adults. Respirology 13, 695-702 (2008).

62. Al-kalemji, A. et al. Factors influencing quality of life in asthmatics-a case-control study. Clin. Respir. J. 7, 288-296 (2013).

63. Petrie, K. \& Weinman, J. Why illness perceptions matter. Clin. Med. 6, 536-539 (2006).

64. Gerald, J. K. \& Moreno, F. A. Asthma and depression: it's complicated. J. Allergy Clin. Immunol. Pract. 4, 74-75 (2016).

65. Barton, C., Clarke, D., Sulaiman, N. \& Abramson, M. Coping as a mediator of psychosocial impediments to optimal management and control of asthma. Respir. Med. 97, 747-761 (2003).

66. Yorke, J., Fleming, S., Shuldham, C., Rao, H. \& Smith, H. Nonpharmacological interventions aimed at modifying health and behavioural outcomes for adults with asthma: a critical review. Clin. Exp. Allergy 45, 1750-1764 (2015).

67. Lavoie, K. L., Bacon, S. L., Labrecque, M., Cartier, A. \& Ditto, B. Higher BMI is associated with worse asthma control and quality of life but not asthma severity. Respir. Med. 100, 648-657 (2006).

68. Pakhale, S., Baron, J., Dent, R., Vandemheen, K. \& Aaron, S. D. Effects of weight loss on airway responsiveness in obese adults with asthma: does weight loss lead to reversibility of asthma? Chest 147, 1582-1590 (2015).

69. Juniper, E., Guyatt, G., Cox, F., Ferrie, P. \& King, D. Development and validation of the mini asthma quality of life questionnaire. Eur. Respir. J. 14, 32-38 (1999).

70. Breslin, F. C., Gnam, W., Franche, R.-L., Mustard, C. \& Lin, E. Depression and activity limitations: examining gender differences in the general population. Soc. Psychiatry Psychiatr. Epidemiol. 41, 648-655 (2006).

71. Hassan, M., Joshi, A., Madhavan, S. \& Amonkar, M. Obesity and health-related quality of life: a cross-sectional analysis of the US population. Int. J. Obes. 27, 1227-1232 (2003).

72. Fortin, M. et al. Multimorbidity and quality of life in primary care: a systematic review. Health Qual. Life Outcomes 2, 51 (2004).

73. Popay, J. et al. Guidance on the Conduct of Narrative Synthesis in Systematic Reviews. A Product from the ESRC Methods Program. Version 1 (Lancaster University, 2006).

74. Downes, M. J., Brennan, M. L., Williams, H. C. \& Dean, R. S. Development of a critical appraisal tool to assess the quality of cross-sectional studies (AXIS). BMJ Open 6, e011458 (2016)

\section{AUTHOR CONTRIBUTIONS}

S.S.-conception of the review, synthesis, wrote the first draft, commented on drafts. B.A. and S.K.-conception of the review and day-to-day conduct of the review, commented on drafts, updated the review, revised the paper. M.T.-conception of the review, commented on drafts. L.Y.-conception of the review, commented on drafts. All authors read and approved the final version of the manuscript.

\section{COMPETING INTERESTS}

The authors declare no competing interests.

\section{ADDITIONAL INFORMATION}

Supplementary information is available for this paper at https://doi.org/10.1038/ s41533-019-0149-3.

Correspondence and requests for materials should be addressed to S.S.

Reprints and permission information is available at http://www.nature.com/ reprints

Publisher's note Springer Nature remains neutral with regard to jurisdictional claims in published maps and institutional affiliations.

(c) (i)

Open Access This article is licensed under a Creative Commons Attribution 4.0 International License, which permits use, sharing, adaptation, distribution and reproduction in any medium or format, as long as you give appropriate credit to the original author(s) and the source, provide a link to the Creative Commons license, and indicate if changes were made. The images or other third party material in this article are included in the article's Creative Commons license, unless indicated otherwise in a credit line to the material. If material is not included in the article's Creative Commons license and your intended use is not permitted by statutory regulation or exceeds the permitted use, you will need to obtain permission directly from the copyright holder. To view a copy of this license, visit http://creativecommons. org/licenses/by/4.0/.

(c) The Author(s) 2019 